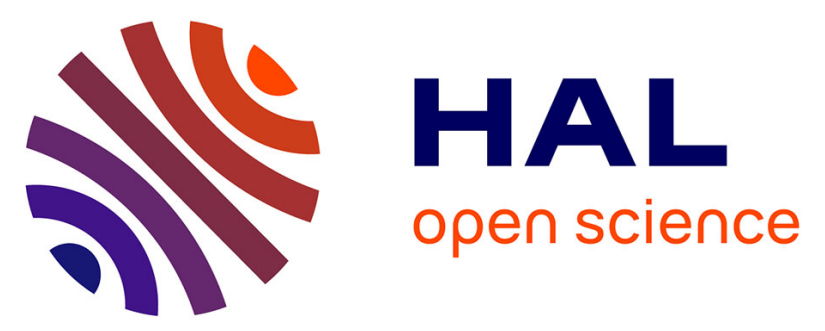

\title{
Diuron effects on photosynthesis and vertical migration of microphytobenthos: Potential rapid bioassessment of herbicide toxicity in coastal sediments
}

Guo-Ying Du, Xue-Feng Zhong, Christine Dupuy, Shuai Che, Johann Lavaud

\section{- To cite this version:}

Guo-Ying Du, Xue-Feng Zhong, Christine Dupuy, Shuai Che, Johann Lavaud. Diuron effects on photosynthesis and vertical migration of microphytobenthos: Potential rapid bioassessment of herbicide toxicity in coastal sediments. Marine Pollution Bulletin, 2021, 170, pp.112619. 10.1016/j.marpolbul.2021.112619 . hal-03265195

\section{HAL Id: hal-03265195 \\ https://hal.science/hal-03265195}

Submitted on 19 Jun 2021

HAL is a multi-disciplinary open access archive for the deposit and dissemination of scientific research documents, whether they are published or not. The documents may come from teaching and research institutions in France or abroad, or from public or private research centers.
L'archive ouverte pluridisciplinaire HAL, est destinée au dépôt et à la diffusion de documents scientifiques de niveau recherche, publiés ou non, émanant des établissements d'enseignement et de recherche français ou étrangers, des laboratoires publics ou privés. 


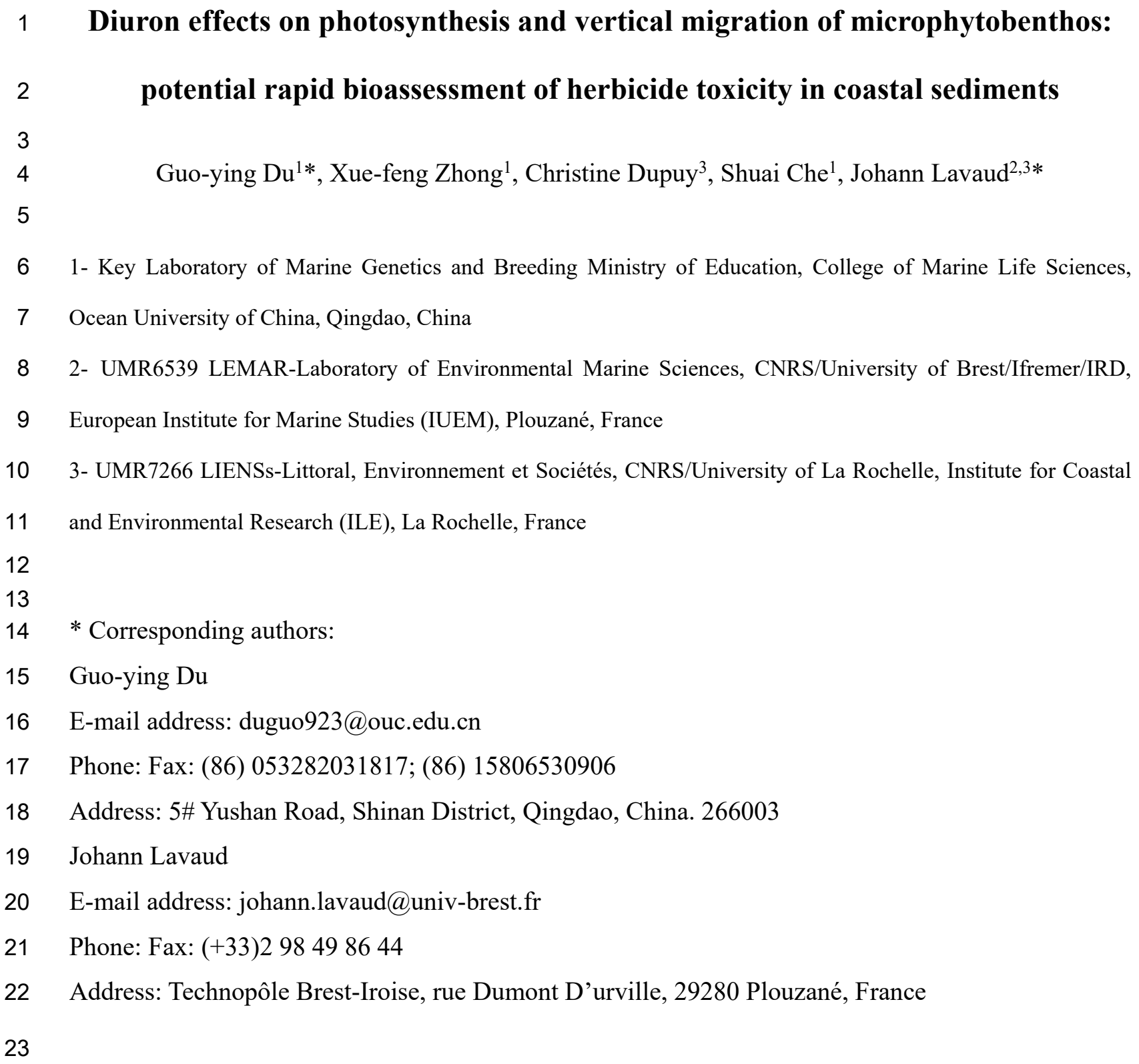




\section{Abstract}

2 The effects of herbicide diuron on photosynthesis and vertical migration of intertidal 3 microphytobenthos (MPB) assemblages were investigated using chlorophyll fluorometry. The results 4 shown diuron $\leq 60 \mu \mathrm{g} \cdot \mathrm{L}^{-1}$ had no obvious effect on MPB vertical migration during $24 \mathrm{~h}$ indicated by 5 consistent rhythm. Low concentration of $10 \mu \mathrm{g} \cdot \mathrm{L}^{-1}$ diuron had no significant influence on MPB 6 photosynthesis throughout, however, high concentrations of 40, 50, and $60 \mu \mathrm{g} \cdot \mathrm{L}^{-1}$ had significant

7 impacts exhibited by decreased parameters of maximum relative electron transport rate (rETR $\max$ ), 8 maximal PS II quantum yield $\left(\mathrm{F}_{\mathrm{v}} / \mathrm{F}_{\mathrm{m}}\right)$ and non-photochemical quenching (NPQ). For middle 9 concentrations of 20 and $30 \mu \mathrm{g} \cdot \mathrm{L}^{-1}$, above decreased 3 parameters recovered sooner or later after $2 \mathrm{~h}$ 10 or $16.5 \mathrm{~h}$. Comparatively, $\mathrm{rETR}_{\max }, \mathrm{F}_{\mathrm{v}} / \mathrm{F}_{\mathrm{m}}$ and NPQ are concentration dependent and more sensitive 11 than other parameters in assessing diuron toxicity. This study revealed the potential of using MPB 12 assemblages and chlorophyll fluorometry for rapid assessing diuron toxicity in coastal sediments.

14 Keywords: microphytobenthos, photosynthesis, vertical migration, diuron, herbicide toxicity, 15 bioassessment

17 Heading: diuron effects on microphytobenthos 


\section{Introduction}

Diuron (3-(3,4-dichlorophenyl)-1,1-dimethylurea, DCMU), as a urea-type herbicide has been

3 effectively used to control a wide variety of grasses and weeds on cotton, coffee, sugar cane, and

4 citrus farms (Coelho-Moreira et al., 2018). Apart from this, the organic biocide diuron has gained

5 popularity as an antifouling agent in paints, especially to prevent fouling of algae on ship hulls and

6 boats (Chesworth et al., 2004; Mukherjee et al., 2009). Incidentally, this kind of herbicide has been

7 released to the freshwater and marine environments inevitably for more than 20 years. Due to its low

8 solubility (42 mg mL $\mathrm{mL}^{-1}$ at $25^{\circ} \mathrm{C}$ ), long persistence in soil (4-8 months) and chemical stability in

9 water, diuron tends to accumulate in the environment (Tixier et al., 2001). It has been detected not

10 only in ground and freshwater systems (Nitschke and Schüssler,1998; Bruggen and Vandecasteele,

11 2003), but also in coastal water and sediments (Jones et al., 2003; Ali et al., 2014; Holmes, 2014).

12 As a universal PSII inhibitory herbicide, diuron can directly inhibits non-target photosynthetic organisms (Haynes et al., 2000; Jones, 2005). Besides, diuron's harms to human and animals have already been reported in numbers of literatures, causing diseases such as mutagenic, metabolic, abnormalities of the liver and spleen, and problems in the transport and release of natural hormones (US Government, 2005; Wong et al., 2013; Simões et al., 2017). All these make diuron a threat to the assessment reports (US Government, 2005; Australian Government, 2011) and related researches

20 have been carried out over the past two decades (OECD, 2006; Magnusson et al., 2008; Kumar et al., 2010; Negri et al., 2015). on terrestrial plants (Australian Government, 2011; Holmes, 2014). In coastal ecosystems, some publications showed the toxicity of diuron for benthic photosynthetic organisms exposed through the water phase, which has been implicated in negative impacts on seagrass (Haynes et al., 2000), mangroves (Duke et al., 2005; Duke, 2008), coral (Jones et al., 2003; Negri et al., 2005, 2011),

27 cyanobacteria (Stingaciu et al., 2019), and benthic microalgae (Magnusson et al., 2008, 2012). 28 Standard toxicity tests have been conducted by exposing photosynthetic organisms to diuron in water 29 (USEPA, 1996; OECD, 2006). In terms of risk characterization, the dataset had been consequently 
applied in risk quotients of these organisms (Australian Government, 2011). Following these criteria, within the catchments and waters of the Great Barrier Reef, diuron is frequently detected in aquatic and marine water quality monitoring programs (Shaw et al., 2010; Kennedy et al., 2012; Lewis et al., 2012; Smith et al., 2012). However, those datasets have not yet established for benthic flora or fauna when exposed to diuron through the sediment due to short of investigations.

Microphytobenthos (MPB) is a group of photosynthetic organisms living in the upper several millimetres of sediments where light reaches, and frequently dominated by diatoms in coastal flats (Admiraal et al., 1984; MacIntyre et al., 1996; Underwood and Kromkamp, 1999). With short life cycle and relevant stable position in the sediment, benthic diatoms are very suitable indicators for monitoring the status of ecological environment. In freshwater system, there have been already numerous publications deliberated it (Kelly and Whitton, 1995; Potapova and Charles, 2007; Stevenson et al., 2010; Bere and Tundisi, 2012; Chen et al., 2016). It is widely used benthic diatoms as Biological Diatom Index (BDI; Coste et al, 2009) in the Water Framework Directive (EU Directive 2000/60/EC) for assessing freshwater system. Theoretically, MPB is very potential bioindicator to monitor or detect toxicity of pollutants in coastal ecosystems. Desrosiers et al. (2013) has proposed that using benthic diatoms for assessing water quality of coastal environments.

MPB shows high photosynthetic capacity and efficient protection against photoinhibition through both physiological and behavioural mechanisms (Serôdio et al., 2006; Cartaxana et al., 2011; Lavaud and Goss, 2014; Barnett et al., 2015; Laviale et al., 2015). Physiological photoprotection mainly depends on distinct xanthophyll pigments, diadinoxanthin and diatoxanthin, which support the dissipation of excessive light energy (the so-called non-photochemical quenching process) and protect PSII reaction centres (Barnett et al., 2015; Cartaxana et al., 2016; Frankenbach et al., 2018; Pniewski and Piasecka-Jędrzejak, 2020). Behavioural photoprotection is realized through the vertical migration of MPB within the uppermost layers of sediment, by which motile diatoms position themselves at suitable depth for optimal light conditions (Consalvey et al. 2004; Barnett et al., 2020). Disturbed or inhibited motility can impair MPB photosynthetic capacity, especially under high irradiance and/or prolonged illumination (Laviale et al., 2015; Cartaxana et al., 2016; Du et al., 2018; Frankenbach et al., 2018).

This study aimed through applying gradients of diuron on natural MPB assemblages to detect 
1 their effects on MPB photosynthetic activities and behaviour characteristics of vertical migration,

2 and monitor the duration of these effects during a whole day. The imaging chlorophyll fluorescence

3 techniques were used to ensure prompt and non-destructive measurement, and assist further

4 assessment of diuron toxicity in sediment.

6 2. Materials and methods

7 Sediment samples were collected from the intertidal mudflat of Aiguillon Bay $\left(47^{\circ} 00^{\prime} \mathrm{N}, 1^{\circ} 05^{\prime}\right.$

8 W) La Rochelle, France, on $18^{\text {th }}$ February, 2015. The sampling site is composed of fine muddy 9 sediments (more than $90 \%$ of grain size $<63 \mu \mathrm{m}$ ) where microphytobenthic biofilm is largely 10 dominated by epipelic diatoms, especially species of genera Navicula and Gyrosigma (Du et al. 11 2017). The surface layers of sediment (top $\sim 0.5 \mathrm{~cm}$ ) were collected using a spatula.

12 In the laboratory, the sediment was sieved through a $500 \mu \mathrm{m}$ mesh to remove the meio- and macrofauna, such as nematodes and sand hoppers, and was thoroughly mixed and spread in $4 \mathrm{~cm}$ 14 deep plastic trays. The stock solution of diuron $\left(0.05 \mathrm{~g} \mathrm{~L}^{-1}\right)$ was made up in $95 \%$ ethanol. In individual glass beakers, corresponding amounts of the solution were diluted with $\mathrm{dH}_{2} \mathrm{O}$ and mixed well with sediment samples to reach final concentrations of $0,10,20,30,40,50$ and $60 \mu \mathrm{g} \mathrm{L}^{-1}$.

17 Beside the blank control of $0 \mu \mathrm{g} \mathrm{L}^{-1}$ diuron, to check the influence of solvent, the same amount of $1895 \%$ ethanol that equal to that of stock solution used for $60 \mu \mathrm{g} \mathrm{L} \mathrm{L}^{-1}$ diuron was applied in sediment samples to be as the ethanol control. Each $3 \mathrm{~mL}$ well mixed sediments were transferred into a well of 24-well plates using pipette. Each concentration had 3 replicates, and two sets of well-plates were prepared. A minimum of $30 \mathrm{~min}$ was allowed for the well-plate system with diuron and MPB assemblages to stabilize before measurements started.

Chlorophyll fluorescence was measured using an Imaging-PAM fluorometer (Max/L, Walz, 24 Germany) for $24 \mathrm{~h}$ during $18^{\text {th }}$ to $19^{\text {th }}$ February. Before measuring fluorescence, areas of interest 25 (AOIs) were defined under Live Video Mode, with circular samples of the same size as internal 26 diameter of well in 24 well-plates. The same AOIs were used consistently over the course of the 27 experiment. Fluorescence was induced by royal blue $(450 \mathrm{~nm}) 3 \mathrm{~W}$ Luxeon LEDs, with a standard 28 intensity of $0.5 \mu \mathrm{mol}$ photons $\mathrm{m}^{-2} \mathrm{~s}^{-1}$ and a modulation frequency between 1 and $8 \mathrm{~Hz}$. The current fluorescence yield, $\mathrm{F}_{\mathrm{t}}$, for monitoring surface MPB abundance were measured at $900 \mathrm{~s}$ intervals 
using one set of well-plate samples for $24 \mathrm{~h}$. The other set of well-plate samples was incubated under "ambient filtered true light" conditions (i.e., light passing by the window of the laboratory, 24-h natural photoperiod, no direct sunlight). The room conditions in laboratory were stable around $15^{\circ} \mathrm{C}$ temperature and $60 \%$ humidity. The rapid light curves (RLCs) were measured to assess the photosynthetic activity, by exposing to 7 incremental steps of actinic light (30 s per step) ranging from 0 to $610 \mu \mathrm{mol}$ photons $\mathrm{m}^{-2} \mathrm{~s}^{-1}$ (PAR, photosynthetically active radiation). The measurement of RLCs were taken after 15 min dark-adaptation at 6 different times during the whole experiment. To check the short-time effect of diuron, RLC measures were carried at $1 \mathrm{~h}$ intervals in the daytime of the first day. To monitor the persisting of diuron effect or MPB recovery from it, in the next day, RLC measures were taken at the beginning and the end of the day respectively. For each irradiance level $(E)$, the relative electron transport rates (rETR) was calculated from the product of $E$ and the PSII effective quantum yield $\left(\mathrm{Y}(\mathrm{II})=\left(\mathrm{F}_{\mathrm{m}}{ }^{\prime}-\mathrm{F}\right) / \mathrm{Fm}_{\mathrm{m}}{ }^{\prime}\right), \mathrm{rETR}=E \times\left(\mathrm{Fm}_{\mathrm{m}}{ }^{\prime}-\mathrm{F}\right) / \mathrm{Fm}_{\mathrm{m}}$ (Genty et al., 1989), where the $\mathrm{F}$ is fluorescence yield, $\mathrm{F}_{\mathrm{m}}$ ' is maximum fluorescence under the highest actinic light of RLC. The photosynthetic parameters, the maximum relative electron transport rate $(\mathrm{rETR} \max )$, maximum light utilization coefficient $(\alpha)$ and the minimum saturation irradiance $\left(E_{\mathrm{k}}\right)$ were derived from the RLCs, referring the model of Platt et al. (1980), ETR $=\operatorname{ETR}_{\max }\left(1-\exp \left(-\alpha \times E / \mathrm{ETR}_{\max }\right)\right), E_{\mathrm{k}}$ $=$ ETR $_{\max } / \alpha$. The maximal PS II quantum yield $\left(\mathrm{F}_{\mathrm{v}} / \mathrm{F}_{\mathrm{m}}\right)$ was calculated as $\left(\mathrm{F}_{\mathrm{m}}-\mathrm{F}_{0}\right) / \mathrm{F}_{\mathrm{m}}$, where $\mathrm{F}_{0}$ is the dark fluorescence yield and $\mathrm{F}_{\mathrm{m}}$ is maximum fluorescence yield after dark adaptation. The non-photochemical quenching (NPQ) was calculated as ( $\left.\mathrm{Fm}_{\mathrm{m}}-\mathrm{F}_{\mathrm{m}}{ }^{\prime}\right) / \mathrm{Fm}_{\mathrm{m}}$ ' (Maxwell and Johnson, 2000).

Statistical analysis was carried out using SPSS 21.0 (SPSS Inc., Chicago, IL, USA). To test the effect of diuron on migration, separate one-way ANOVAs were run on $F_{t}$ for each treatment, followed by the Tukey's HSD- post-hoc tests to compare paired difference. To compare the effects of different diuron concentrations on photosynthesis, T-test were run for each treatment on the variables of rETR, $\mathrm{rETR}_{\max }, \alpha, E_{\mathrm{k}}, \mathrm{F}_{\mathrm{v}} / \mathrm{F}_{\mathrm{m}}$ and NPQ at individual measuring time.

\section{Results}

\subsection{Chlorophyll fluorescence yield $\left(F_{t}\right)$ variations}

Indicated by $\mathrm{F}_{\mathrm{t}}$, distinct variations of surface MPB abundance along with experiment time were illustrated in Figure 1. Under weak measuring light of $\mathrm{F}_{\mathrm{t}}\left(0.5 \mu \mathrm{mol}\right.$ photons $\left.\mathrm{m}^{-2} \mathrm{~s}^{-1}\right)$, the natural 
1 MPB assemblage which had been artificially mixed homogenously with sediments still exhibited

2 their endogenous migration up to the surface. Besides the initial rapid increase at the beginning, there

3 was steeply ascending $F_{t}$ from AM 3:30 to 5:00 during the early morning of the next day before

4 sunrise, and followed by relatively smoothly increase till the midday around 12:00. Relatively

5 decreased $F_{t}$ happened around PM 20:30 and AM 2:00 (the next day) during night. In the next day,

6 after midday peak, the $F_{t}$ slowly declined until the end of experiments. Averagely, the Ft of the next

7 day was twice higher than that of the first day. Overall, there was no significant difference between

8 the different treatments for all measured $F_{t}$ (Tukey HSD test, $P>0.05$ ), especially for treatments of

9 diuron concentration less than $40 \mu \mathrm{g} \mathrm{L}^{-1}$, there was no concentration dependent difference along with

10 the experiment time. However, it illustrated two trends which are worthy of further study. One is the

11 blank control $\left(0 \mu \mathrm{g} \mathrm{L}^{-1}\right)$ presented the largest variation $(\mathrm{SD}, \pm 0.717)$ throughout the whole

12 experiment with relatively lower $\mathrm{F}_{t}$ during night and higher $\mathrm{F}_{\mathrm{t}}$ during day than other treatments. The

13 another is the high concentration of 50 or $60 \mu \mathrm{g} \mathrm{L}-1$ generally induced the lowest $\mathrm{F}_{\mathrm{t}}$. Especially for 60

$14 \mu \mathrm{g} \mathrm{L}{ }^{-1}$ in the next day, the difference became significant with 20 or $40 \mu \mathrm{g} \mathrm{L}^{-1}$ since 10:49 (after 18.5h

15 exposure, paired t-test, $P<0.05)$, but still not significant with the remained treatments including

16 controls (paired t-test, $P>0.05$ ). Overall, the results indicated that no significant diuron effects on

17 vertical migration of MPB within $60 \mu \mathrm{g} \mathrm{L}^{-1}$ concentration during $24 \mathrm{~h}$ experiment period.

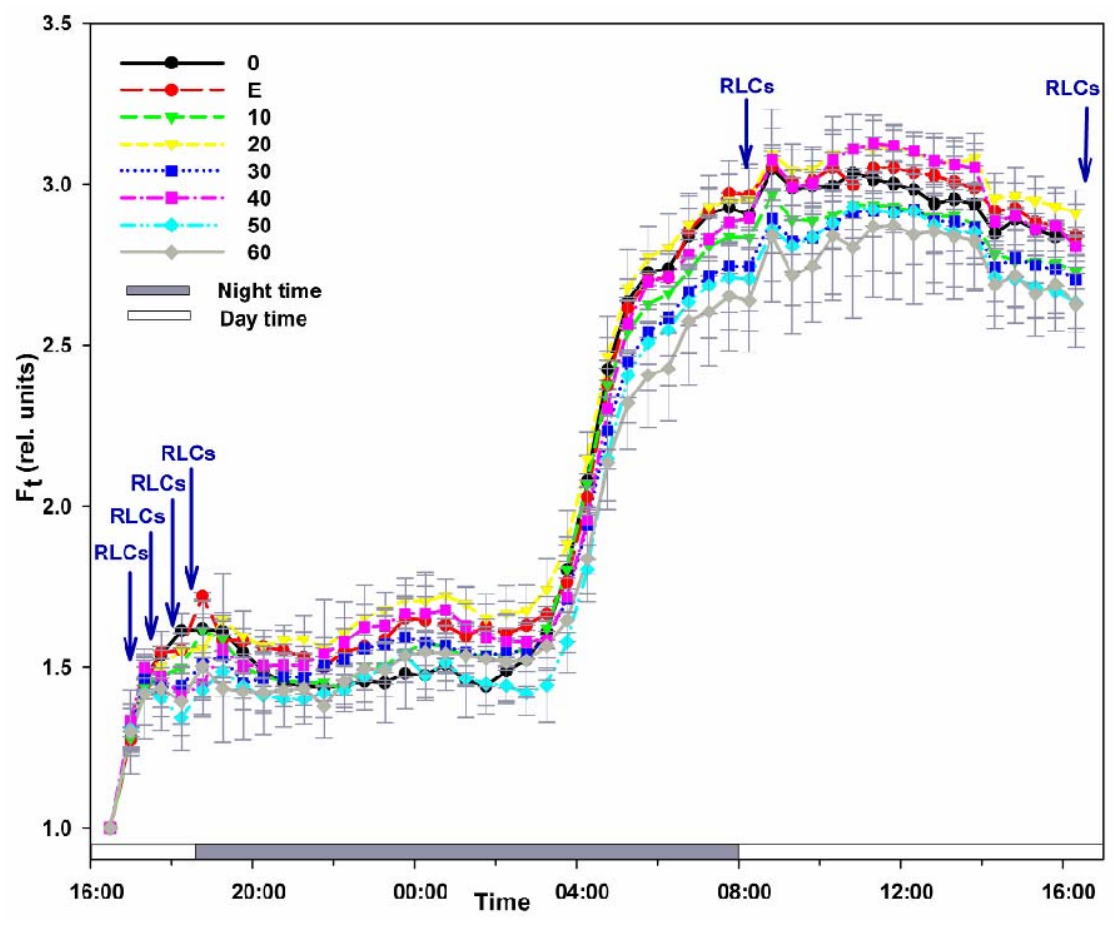


1 Fig. 1. $\mathrm{F}_{\mathrm{t}}$ variations along with time under different treatments (shown as 30 min interval and normalized to initial

2 values). Concentrations of $0,10,20,30,40,50,60 \mu \mathrm{g} \mathrm{L}^{-1}$ diuron are represented by numbers, and ethanol control is

3 labelled as E; dark grey bar, night time; blank bar, day time of natural photoperiod. RLCs (rapid light curves)

4 arrows point the timing at which RLCs were performed.

$5 \quad 3.2$ Rapid light curves (RLCs) and photosynthetic parameters

6 RLCs generated by PAM fluorometers presented MPB photosynthetic activity of different 7 treatments. It showed a similar relation pattern of different treatments at 6 measuring time (Fig. 2).

8 The RLCs of blank and ethanol control always accompanied closely and presented increasing rETR

9 along with incremental light intensity more rapidly than other treatments. On the contrary, the high 10 diuron concentrations of 50 and $60 \mu \mathrm{g} \mathrm{L}^{-1}$ constantly induced the most slowly increasing rETR along 11 with light intensity. After $1.5 \mathrm{~h}$ exposure, the RLCs of $10 \mu \mathrm{g} \mathrm{L} \mathrm{L}^{-1}$ diuron almost overlapped with those 12 of blank or ethanol control. The RLCs of $40 \mu \mathrm{g} \mathrm{L}^{-1}$ diuron always closed to those of $50 \mu \mathrm{g} \mathrm{L}{ }^{-1}$ diuron. 13 The RLCs of 20 and $30 \mu \mathrm{g} \mathrm{L}^{-1}$ diuron were always in the middle of all curves at each measuring 14 time. 


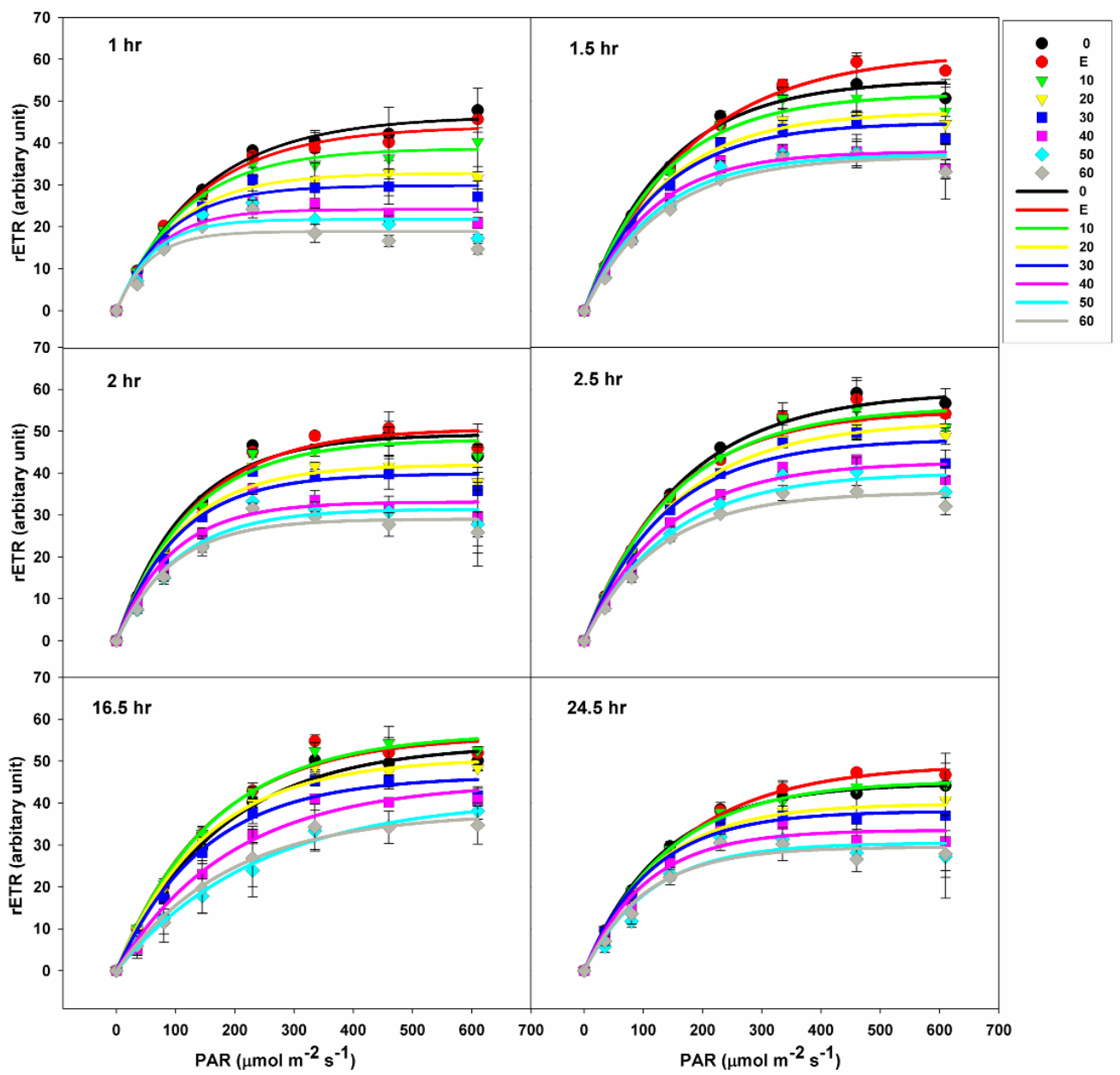

Fig. 2. Rapid light curves (RLCs) with corresponding fitting curves of the different treatments at 6 measuring time, which are marked by blue arrows in Fig. 1 with starting timing $0 \mathrm{hr}$ of the experiment beginning. Treatments symbols of $0,10,20,30,40,50,60 \mu \mathrm{g} \cdot \mathrm{L}^{-1}$ diuron are represented by numbers and ethanol control by $\mathrm{E}$. The monochrome lines represent corresponding fitting curves (Platt et al., 1980).

Five key photosynthetic parameters derived from fluorescence measurement were illustrated their variation under different treatments at 6 measuring time (Fig.3).

Revealed by rETR max, the diuron toxicity distinctly affected MPB photosynthetic ability under different treatments (Fig. 3a). It showed that the rETR $_{\max }$ under high concentrations of 40, 50 and 60 $\mu \mathrm{g} \mathrm{L} \mathrm{L}^{-1}$ were significantly lower than other treatments $(P<0.01$ or 0.05$)$, especially at the early period $(P<0.01)$. There was no difference of $10 \mu \mathrm{g} \mathrm{L}^{-1}$ diuron with controls on $\mathrm{rETR} \max$ throughout the whole experiment $(P>0.05)$. Comparing to blank control, the inhibition of $20-60 \mu \mathrm{g} \mathrm{L}^{-1}$ diuron on $\mathrm{rETR}_{\max }$ was more distinct under $1 \mathrm{~h}$ exposure, but for lower concentrations of 20 and $30 \mu \mathrm{g} \mathrm{L}^{-1}$ diuron, the inhibition recovered from $2 \mathrm{~h}$. However, for high concentrations of 40 to $60 \mu \mathrm{g} \mathrm{L} \mathrm{L}^{-1}$ 
diuron, no recovery happened until the end of the experiment $(24.5 \mathrm{~h})$.

The diuron effect on the maximum light utilization coefficient $(\alpha)$ exhibited less difference than on rETR $_{\max }$ (Fig. 3b). There was no difference of $\alpha$ among all treatments under $1 \mathrm{~h}$ exposure. Comparing to blank control, 10-30 $\mu \mathrm{g} \mathrm{L}^{-1}$ diuron had no significant effect on $\alpha$ throughout the experiment $(P>0.05), 40 \mu \mathrm{g} \mathrm{L}^{-1}$ diuron induced significantly different $\alpha$ from $1.5 \mathrm{~h}$ to $16.5 \mathrm{~h}$ exposure $(P<0.01$ or 0.05$)$, while 50 and $60 \mu \mathrm{g} \mathrm{L}^{-1}$ diuron resulted in significant difference from 1.5 $\mathrm{h}$ till to the end of the experiment $(24.5 \mathrm{~h})(P<0.01$ or 0.05$)$.

For the minimum saturation irradiance $\left(E_{\mathrm{k}}\right)$, only $40-60 \mu \mathrm{g} \mathrm{L}^{-1}$ diuron caused significantly different $E_{\mathrm{k}}$ with controls under $1 \mathrm{~h}$ exposure $(P<0.05$, Fig.3c). After $1 \mathrm{~h}$, no significant difference existed in $E_{\mathrm{k}}$ of each treatment from control.

The maximal PS II quantum yield $\left(\mathrm{F}_{\mathrm{v}} / \mathrm{F}_{\mathrm{m}}\right)$ which indicated the photosynthetic capacity presented the similar trend as the rETRmax (Fig. 3d). Besides no difference on $F_{v} / F_{m}$ between $10 \mu g L^{-1}$ diuron and controls $(P>0.05)$, the difference among treatments was still distinct throughout the experiment. For 20 and $30 \mu \mathrm{g} \mathrm{L} \mathrm{L}^{-1}$ diuron, the significant impacts on $\mathrm{F}_{\mathrm{v}} / \mathrm{F}_{\mathrm{m}}$ recovered for a longer time as $16.5 \mathrm{~h}$ and $24.5 \mathrm{~h}$ respectively, however, for high concentrations of 40 to $60 \mu \mathrm{g} \mathrm{L} \mathrm{L}^{-1}$ diuron, the effects were significant throughout the whole experiment $(P<0.01$ or 0.05$)$.

Comparing to above 4 parameters, the non-photochemical quenching (NPQ) exhibited more distinct difference among treatments at each measuring time, except at the dawn of the second day (16.5h, Fig.3e). The $10 \mu \mathrm{g} \mathrm{L} \mathrm{L}^{-1}$ diuron still showed no significant effect on NPQ indicated by no difference with the controls $(P>0.05)$. The 20 and $30 \mu \mathrm{g} \mathrm{L}^{-1}$ diuron had identical significant effects on lowering NPQ from $1 \mathrm{~h}$ to $2.5 \mathrm{~h}$ exposure $(P<0.01$ or 0.05$)$. At the dawn of the second day (16.5h), it showed the effects of 20 and $30 \mu \mathrm{g} \mathrm{L} \mathrm{L}^{-1}$ diuron were not significant due to the whole dropping of NPQ values, however, for $30 \mu \mathrm{g} \mathrm{L}-1$ diuron the effect became significant again at $24.5 \mathrm{~h}$ along with increased NPQ of all treatments $(P<0.05)$. The high diuron concentrations of 40,50 and $60 \mu \mathrm{g} \mathrm{L}^{-1}$ brought significant impacts on NPQ over whole experiment $(P<0.01$ or 0.05$)$ and exhibited significant difference among themselves in the first day from $1.5 \mathrm{~h}$ to $2.5 \mathrm{~h}$ exposure $(P<$ 0.01 or 0.05$)$. 

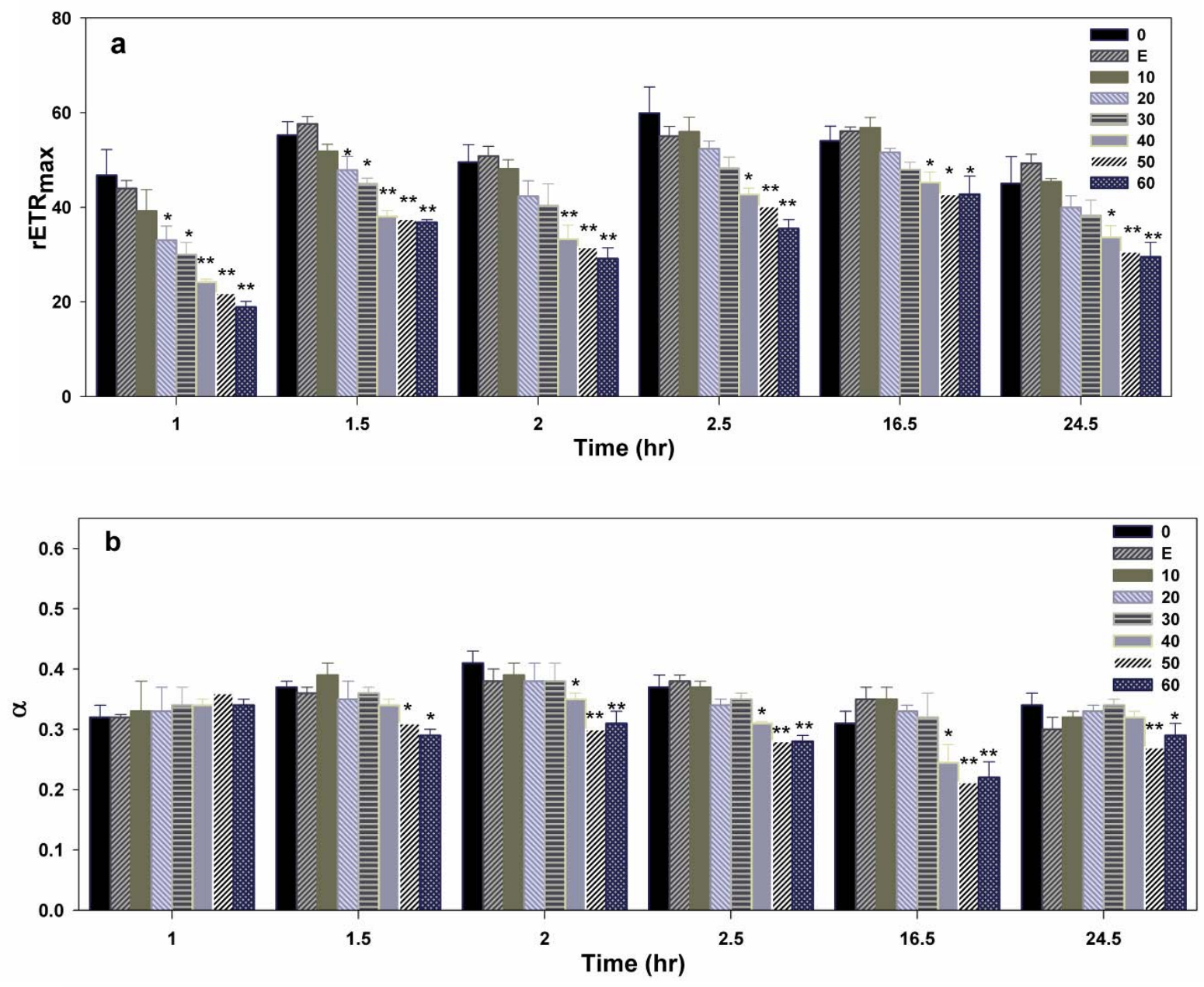

2

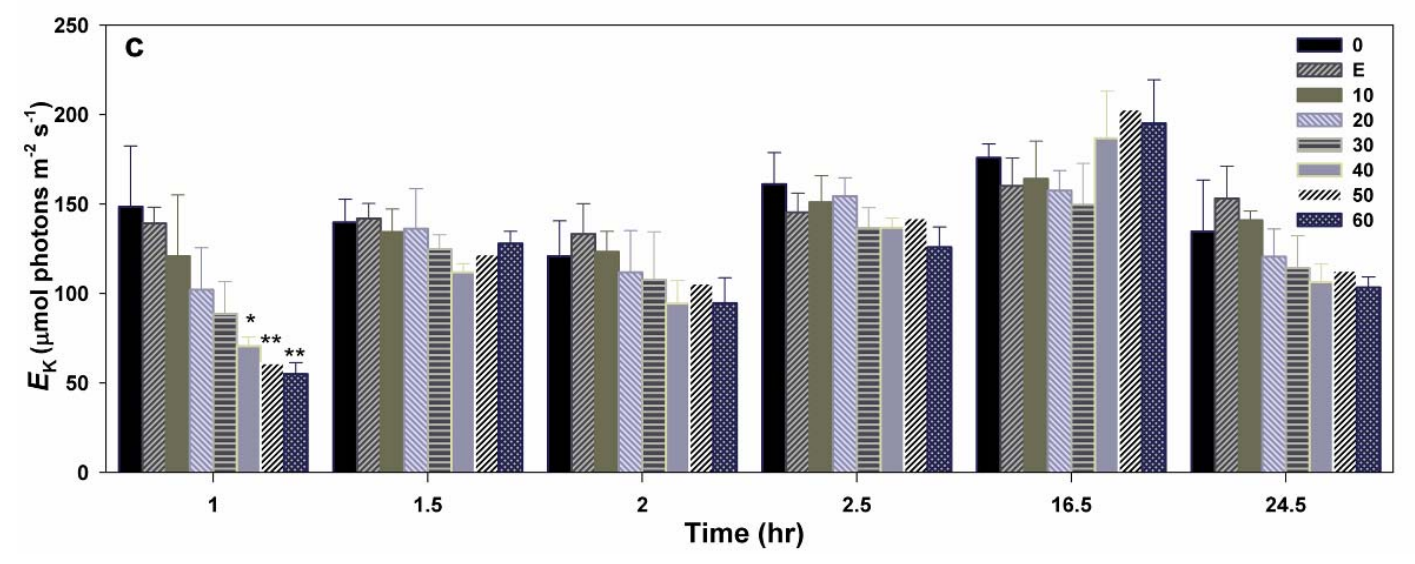



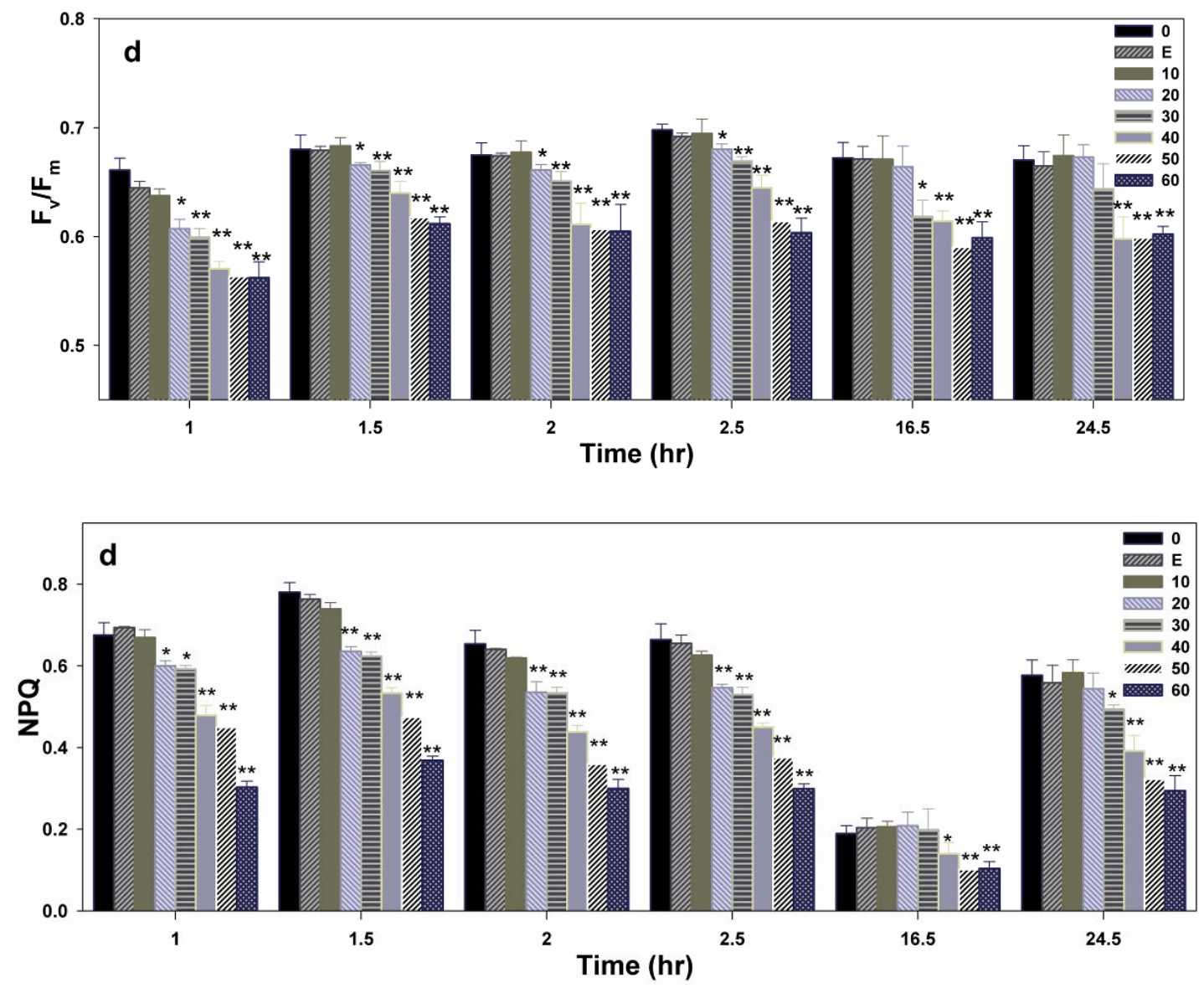

2

3 Fig 3. Variations of photosynthetic parameters under different treatments as a function of experiment time (hr). a,

4 maximum relative electron transport rate $\left(\mathrm{rETR}_{\max }\right)$; b, light utilization coefficient $(\alpha)$; $\mathrm{c}$, minimum saturation

5 irradiance $\left(E_{\mathrm{k}}\right) ; \mathrm{d}$, maximal PS II quantum yield $\left(\mathrm{F}_{\mathrm{v}} / \mathrm{F}_{\mathrm{m}}\right)$; e, non-photochemical quenching (NPQ). Concentrations

6 of $0,10,20,30,40,50,60 \mu \mathrm{g} \mathrm{L}^{-1}$ diuron are represented by numbers, and ethanol control is labelled as E. Symbols

\section{Discussion}

\section{Diuron effects on microphytobenthos (MPB) photosynthesis}

Diuron inhibition on photosynthesis has been observed in all kinds of aquatic plants and algae, with differences in both toxicity degree and minimum toxicity concentration both of which depend on exposure time. For brown macroalga Saccharina japonica, after 2 weeks exposure to diuron, it 
presented a concentration dependent decrease on photosynthetic parameters of $\mathrm{F}_{\mathrm{v}} / \mathrm{F}_{\mathrm{m}}$ and $\mathrm{ETR} \max$

2 along with incremental concentration from 0.1 to $0.4 \mathrm{mg} \mathrm{L}^{-1}$ (in water) and a complete inhibition of 3 electron transport at $0.4 \mathrm{mg} \mathrm{L}^{-1}$ (Kumar et al., 2010). For seagrass Zostera marina, the EC20 of 4 diuron revealed that the lowest concentration was $0.5 \mu \mathrm{g} \mathrm{\textrm {L } ^ { - 1 }}$ for significant effect on growth and 5 photosynthetic efficiency in 10 days (Chesworth et al., 2004). Other two tropical seagrass Halodule 6 uninervis and Z. mueller were significantly inhibited by $0.3 \mu \mathrm{g} \mathrm{L}^{-1}$ diuron on their photosynthetic 7 efficiency $\left(\mathrm{F}_{\mathrm{v}} / \mathrm{F}_{\mathrm{m}}\right.$ and $\left.\mathrm{Y}(\mathrm{II})\right)$ over a 11-week exposure period (Negri et al., 2015). In the first study of 8 diuron toxic effects on tropical MPB (diatom Navicula sp. and chlorophyte Nephroselmis pyriformis), 9 growth and photosynthetic efficiency were reduced by $10 \%$ when exposed to diuron concentrations 10 as low as $0.5 \sim 2 \mu \mathrm{g} \mathrm{L} \mathrm{L}^{-1}$ for 3 days (Magnusson et al., 2008).

11 These above studies were all carried out for a longer exposure time from 3 days to 11-week and 12 tested the diuron toxicity in water. However, in the present study, natural MPB assemblages was used to test the diuron toxicity in sediments during shorter time within $24.5 \mathrm{~h}$. It shown that the 14 lowest diuron concentration of $10 \mu \mathrm{g} \mathrm{L}^{-1}$ had no obvious effect on MPB photosynthesis, while, from $1520 \mu \mathrm{g} \mathrm{L}^{-1}$ to $60 \mu \mathrm{g} \mathrm{L} \mathrm{L}^{-1}$, it presented a concentration dependent decrease in the photosynthetic activity. 16 Under this situation, the minimum toxicity concentration on MPB could be $40 \mu \mathrm{g} \mathrm{L}^{-1}$ for $1 \mathrm{~h}$ till to $1724.5 \mathrm{~h}$. Because the impact of 20 or $30 \mu \mathrm{g} \mathrm{L} \mathrm{L}^{-1}$ was mostly evident within $2 \mathrm{~h}$ and could recovered sooner or later ( $2 \mathrm{~h}$ or $16.5 \mathrm{~h})$ according to individual parameters, if using them as minimum toxicity concentration, the testing time and parameters should be considered together. Nevertheless, our study suggested a very short time as $1 \mathrm{~h}$ for assessing diuron toxicity. Cho et al. (2008) also proposed that short time as $2 \mathrm{~h}$ for suspended microalgae to predict EC50 values using a photosynthetic activity measurement system (substantially dissolved oxygen meter) for rapid toxicity assessment. It corroborated our study on supplying a potential rapid method instead of the conventional algal assay, 24 in which $96 \mathrm{~h}$ is recommended for assessing toxicity based on algal growth rate (U.S. EPA, 1996 and 25 OECD guidelines, 2002).

26 Previous studies almost tested diuron toxicity in water on aquatic photosynthetic organisms. 27 Even for MPB Magnusson et al. (2008 and 2010) used suspended cells of tested species and 28 developed an artificial epiphytic biofilm (2012) for assessing, it still tested water phase toxicity. 29 Without directly applying diuron in sediments, it hardly reflects the natural response of benthic flora 
in coastal sediments. Furthermore, diuron, and its toxic degradation products, could persist longer in

2 sediments than in water, potentially imposing longer lasting toxicity (Tixier et al., 2001). Therefore,

3 through mimicking the exposure of MPB in freshly collected mudflat sediments to diuron, our study

4 is specifically practical for assessment diuron toxicity in coastal sediment.

5 It was also noteworthy that, in this study, the recovery of MPB photosynthetic ability under 20

6 and $30 \mu \mathrm{g} \mathrm{L}^{-1}$ diuron concentrations was different according to respective parameters, i.e. recovery

7 was observed after $2 \mathrm{~h}$ exposure for rETRmax, while it needed the overnight period for NPQ and

$8 \mathrm{~F}_{\mathrm{v}} / \mathrm{F}_{\mathrm{m}}$. Such recovery was also observed in other aquatic photosynthetic organisms and very much

9 species-dependent (Negri et al., 2005; Magnusson et al., 2012; Burns et al., 2015; Esteves et al., 2017). Among them, diatoms are often considered as more resistant to and more rapidly recoverable

11 from diuron toxicity (Juneau et al., 2007; Magnusson et al., 2012; Stachowski-Haberkorn, et al., 12 2013), which possibly most thanks to the capability of diatom frustules (porous silica cell-wall) to sort and filter nutrients from harmful agents (De Tomassi et al., 2017). parameters

To assess the environmental toxicity of a contaminant, a biological sensitive parameter with clear concentration-dependent ranging values needs to be defined as a solid toxicity indicator. The chlorophyll fluorescence-derived photosynthetic parameters firstly contribute to a rapid, sensitive and non-invasive assessment based on photosynthetic activity (Juneau et al. 2007; Baker 2008; Murchie et al. 2013). Furthermore, coupled with a well-plate system, the imaging fluorometry (Imaging-PAM) used in this study realized a monitoring on multi-samples at the same time.

As referenced above, several previous studies also used chlorophyll fluorometry to assess the toxicity of diuron on benthic-living photosynthetic organisms, such as $F_{v} / F_{m}$ and ETR max used for brown macroalga (Kumar et al., 2010), $\mathrm{F}_{\mathrm{v}} / \mathrm{F}_{\mathrm{m}}$ and $\mathrm{Y}(\mathrm{II})$ for tropical seagrass (Negri et al., 2015), Y(II) for tropical benthic microalgae (Magnusson et al., 2008 and 2010). Juneau et al. (2007) reviewed chlorophyll fluorescence-derived parameters and considered the $F_{v} / F_{m}$ may not be the best parameter for evaluating toxic effect of herbicides due to its relatively low sensitivity, and rather, proposed better use Y(II) and NPQ since they better integrate the physiological status of the plant. 
In the present study, five derived parameters, $\mathrm{rETR}_{\max }, \alpha, E_{\mathrm{k}}, \mathrm{F}_{\mathrm{v}} / \mathrm{F}_{\mathrm{m}}$, as well as NPQ, were assessed in determining diuron effect. Although all photosynthetic parameters were lowered during

3 the $24.5 \mathrm{~h}$ diuron treatment, the effective concentrations as well as the timings differed among 4 parameters. The $\alpha$ showed a delay reaction over $1 \mathrm{~h}$, and was the most insensitive of the parameters 5 examined, exhibiting relatively stable values especially under 0-30 $\mu \mathrm{g} \mathrm{L}^{-1}$ diuron range. The other 6 derived parameter, $E_{\mathrm{k}}$ presented a more volatile and irregular trends. Comparatively, $\mathrm{rETR}_{\max }, \mathrm{F}_{\mathrm{v}} / \mathrm{F}_{\mathrm{m}}$

7 and NPQ were more sensitive and reliable parameters with clear concentration-dependent ranging 8 values. Although for most tested parameters, the minimum toxicity concentration could be $40 \mu \mathrm{g} \mathrm{L}^{-1}$ 9 diuron as its throughout significant influence, on the other hand, with respect to individual 10 parameters such as $\mathrm{rETR}_{\max }$ and $\mathrm{F}_{\mathrm{v}} / \mathrm{F}_{\mathrm{m}}$, it could be the lowest as $20 \mu \mathrm{g} \mathrm{L}^{-1}$ for only $1 \mathrm{~h}$ exposure time. 11 Besides, compared to others, NPQ could better distinguish the difference among individual diuron 12 concentrations. Juneau et al. (2007) proposed to use a combination of various fluorescence 13 parameters to provide complementary information on the mode of herbicide action. Therefore, based 14 on our study and previous researches, we suggested $r E T R_{\max } / F_{v} / F_{m}$ and NPQ as the combination 15 indicators for diuron toxicity in sediments. Our study also validated the utility of imaging 16 chlorophyll fluorometry as a rapid and reliable technique to measure sub-lethal toxicity threshold.

\section{Indirect effect of diuron on MPB photosynthesis inhibition}

Because photosynthesis is a central process that supports the whole cell metabolism, its inhibition could cause potential effects on other activities. Staats et al. (2000) observed that the secretion of exopolysaccharide (EPS) by motile benthic diatoms was decreased after diuron inhibition on photosynthesis. EPS keenly associates with diatoms motility, especially in building the trails for diatom motility on substrate surface (Edgar and Pickett-Heaps,1984; Hoagland et al. 1993, Molino and Wetherbee, 2008). Even Coquillé et al. (2015) suggested to use diatom motility features as endpoints of herbicide metolachlor toxicity. However, in our study, there was no evidence of diuron-driven differences in vertical migration of natural MPB assemblages during 24.5 hours.

27 Instead, in our conditions, MPB abundance at the surface of sediment indicated by $\mathrm{F}_{t}$ went on 28 varying at the function of photoperiod (and probably of the tidal cycle), with striking increase of $F_{t}$ 29 before day starts (Fig.1) as previously reported before (Consalvey et al. 2004; Barnett et al. 2020). It 
was consistent with the observation of Staats et al. (2000) that in situ patterns of diuron-treated-MPB

2 vertical migration in the dark did not differ from those exposed to light during $24 \mathrm{~h}$ field experiment

3 on mudflat surface. Both studies indicated that although light steers MPB vertical migration, the

4 decrease in photosynthetic activity itself does not seem to directly influence this directive motility of

5 MPB in a short time as $24 \mathrm{~h}$. This phenomenon, from other side, also endows MPB a special ability

6 to actively avoid further exposing to diuron as benthic motile diatoms did in escaping from herbicide

7 metolachlor (Coquillé et al. 2015) and directing to dissolved silicate (Bondoc et al. 2016). Further

8 study needs to explore the possible combined results, because it is crucial in the framework of using

9 chlorophyll fluorometry to bioassess diuron and photosynthesis-impacting contaminants in coastal

10 sediments.

11 As natural assemblages in coastal flats, MPB community dynamics in species composition and

12 biomass are close related to a complex set of environmental factors (MacIntyre et al. 1996;

13 Underwood and Kromkamp 1999). The effect of diuron on MPB also depends on environmental

14 factors such as light and temperatures (Camuel et al., 2017; Chaumet et al., 2020). Therefore, it

15 should be considered these factors when assessing diuron toxicity in situ in different seasons and

16 regions. Furthermore, the influence of diuron on MPB photosynthesis inevitably firstly impacts MPB

17 functions as primary producer in coastal ecosystem. Secondly, according to the findings of

18 class-specific responses of marine benthic microalgae (Magnusson et al.,2008, 2010 and 2012) and

19 species-specific sensitivity of benthic diatoms (Larras et al., 2012; Wood et al., 2016) to herbicide,

20 chronic exposures to diuron also could in turn affect the sensitivity and community structure of MPB

21 (Magnusson et al., 2012). 


\section{Funding}

2 This work was supported financially by the research program 'Invited professorship' of Region

3 Poitou-Charentes, France; and the National Key R\&D Program of China (2018YFC1406704 \&

4 2020YFD0900702). This work was additionally supported by the Centre National de la Recherche

5 Scientifique-CNRS, the University of La Rochelle, the Contrat Plant Etat Région-CPER "Littoral"

$6 \quad 2007-2013$.

8 Declaration of competing interest

9 The authors declare that we have no known competing financial interests or personal relationships

10 that could have appeared to influence the work reported in this paper.

11 CRediT authorship contribution statement

12 Guo-ying Du: planning, conceptualization, methodology, performed the experiments and drafted the 13 original manuscript, Xue-feng Zhong and Shuai Che: performed the data analysis, editing the 14 manuscript; Christine Dupuy: project administration and supervision, funding acquisition, Johann 15 Lavaud: planning, methodology, supervision, reviewing and editing the manuscript. 


\section{References}

Admiraal, W., Peletier, H., \& Brouwer, T. (1984). The seasonal succession patterns of diatom species on an intertidal mudflat: an experimental analysis. Oikos, 30-40. https://doi.org/10.2307/3544606

Ali, H.R., Arifin, M.M., Sheikh, M.A., Shazili, N.A.M., Bakari, S.S., \& Bachok, Z. (2014). Contamination of diuron in coastal waters around Malaysian Peninsular. Marine pollution bulletin, 85(1), 287-291. https://doi.org/10.1016/j.marpolbul.2014.05.049

Australian Government. (2011). Diuron environment assessment. Australian Government-Australian Pesticides and Veterinary Medicines Authority.

Baker, N.R. (2008). Chlorophyll fluorescence: a probe of photosynthesis in vivo. Annual Review of Plant Biology 59:89-113. DOI: 10.1146/annurev.arplant.59.032607.092759

Barnett, A., Méléder, V., Dupuy, C., \& Lavaud, J. (2020). The vertical migratory rhythm of intertidal microphytobenthos in sediment depends on the light photoperiod, intensity, and spectrum: Evidence for a positive effect of blue wavelengths. Frontiers in Marine Science, 7. http://dx.doi.org/10.3389/fmars.2020.00212

Barnett, A., Méléder, V., Blommaert, L., Lepetit, B., Gaudin, P., Vyverman, W., Sabbe, K., Dupuy, C., \& Lavaud, J. (2015). Growth form defines physiological photoprotective capacity in intertidal benthic diatoms. The ISME journal, 9(1), 32-45. https://doi.org/10.1038/ismej.2014.105

Bere, T., \& Tundisi, J.G. (2012). Diatom communities as indicator of ecological impairment in rivers: Conservation and water quality management. Lambert Academic Publishing. Saarbrucken, Germany. DOI:10.13140/2.1.3087.8722.

Bondoc, K., Heuschele, J., Gillard, J., Vyverman, W. , \& Pohnert, G. (2016). Selective silicate-directed motility in diatoms. Nature communications 7, 10540. https://doi.org/10.1038/ncomms10540

Bruggen, B.V.D. \& Vandecasteele, C. (2003). Removal of pollutants from surface water and groundwater by nanofiltration: overview of possible applications in the drinking water industry. Environmental Pollution, 122, 435-445. https://doi.org/10.1016/S0269-7491(02)00308-1

Burns, M., Hanson, M.L., Prosser, R. S., Crossan, A.N., \& Kennedy, I.R. (2015). Growth recovery of Lemna gibba and Lemna minor following a 7-day exposure to the herbicide diuron. Bulletin of environmental contamination and toxicology, 95(2), 150-156. https://doi.org/10.1007/s00128-015-1575-8

Camuel, A., Guieysse, B., Alcántara, C., \& Béchet, Q. (2017). Fast algal eco-toxicity assessment: influence of light intensity and exposure time on Chlorella vulgaris inhibition by atrazine and DCMU. Ecotoxicology and environmental safety, 140, 141-147. https://doi.org/10.1016/j.ecoenv.2017.02.013

Cartaxana, P., Cruz, S., Gameiro, C., \& Kühl, M. (2016). Regulation of intertidal microphytobenthos photosynthesis over a diel emersion period is strongly affected by diatom migration patterns. Frontiers in Microbiology, 7, 872. https://doi.org/10.3389/fmicb.2016.00872

Cartaxana, P., Ruivo, M., Hubas, C., Davidson, I., Serôdio, J., \& Jesus, B. (2011). Physiological versus behavioral photoprotection in intertidal epipelic and epipsammic benthic diatom communities. Journal of Experimental Marine Biology and Ecology, 405(1-2), 120-127. https://doi.org/10.1016/j.jembe.2011.05.027

Chaumet, B., Mazzella, N., Neury-Ormanni, J., \& Morin, S. (2020). Light and temperature influence on diuron bioaccumulation and toxicity in biofilms. Ecotoxicology, 29(2), 185-195. https://doi.org/10.1007/s10646-020-02166-8

Chen, X., Zhou, W., Pickett, S.T., Li, W., Han, L., \& Ren, Y. (2016). Diatoms are better indicators of urban stream conditions: A case study in Beijing, China. Ecological Indicators, 60, 265-274. https://doi.org/10.1016/j.ecolind.2015.06.039

Chesworth, J.C., Donkin, M.E., \& Brown, M.T. (2004). The interactive effects of the antifouling herbicides Irgarol 1051 and Diuron on the seagrass Zostera marina (L.). Aquatic toxicology, 66(3), 293-305. 
https://doi.org/10.1016/j.aquatox.2003.10.002

Cho, C.W., Pham, T.P.T., Jeon, Y.C., Min, J., Jung, H.Y., Lee, D.S., \& Yun, Y.S. (2008). Microalgal photosynthetic activity measurement system for rapid toxicity assessment. Ecotoxicology, 17(6), 455-463. https://doi.org/10.1007/s10646-008-0197-x

Coelho-Moreira, J.D.S, Brugnari, T., Sá-Nakanishi, A.B., Castoldi, R., De Souza, C.G., Bracht, A., \& Peralta, R.M. (2018). Evaluation of diuron tolerance and biotransformation by the white-rot fungus Ganoderma lucidum. Fungal biology, 122(6), 471-478. https://doi.org/10.1016/j.funbio.2017.10.008

Consalvey, M., Paterson, D.M., \& Underwood, G.J. (2004). The ups and downs of life in a benthic biofilm: migration of benthic diatoms. Diatom Research, 19(2), 181-202. https://doi.org/10.1080/0269249X.2004.9705870

Coste,M., Boutry, S., Tison-Rosebery, J., \& Delmas, F. (2009). Improvements of the Biological Diatom Index (BDI): Description and efficiency of the new version (BDI-2006). Ecological Indicators, 9 (4), 621-650. https://doi.org/10.1016/j.ecolind.2008.06.003.

Desrosiers, C., Leflaive, J., Eulin, A., Ten-Hage, L. (2013). Review Bioindicators in marine waters: Benthic diatoms as a tool to assess water quality from eutrophic to oligotrophic coastal ecosystems. Ecological Indicators. 32, 25-34. DOI : 10.1016/j.ecolind.2013.02.021

De Tommasi, E., Gielis, J., \& Rogato, A. (2017). Diatom frustule morphogenesis and function: a multidisciplinary survey. Marine genomics, 35, 1-18. https://doi.org/10.1016/j.margen.2017.07.001

Du, G.Y., Yan, H.M., \& Dupuy, C. (2017). Microphytobenthos as an indicator of environmental quality status in intertidal flats: Case study of coastal ecosystem in Pertuis Charentais, France. Estuarine, Coastal and Shelf Science, 196, 217-226. https://doi.org/10.1016/j.ecss.2017.06.031

Du, G.Y., Yan, H.M., Liu, C.R., \& Mao, Y.X. (2018). Behavioral and physiological photoresponses to light intensity by intertidal microphytobenthos. Journal of Oceanology and Limnology, 36(2), 293-304. https://doi.org/10.1007/s00343-017-6099-0

Duke, N.C. (2008). Corrections and updates to the article by Duke et al. (2005) reporting on the unusual occurrence and cause of dieback of the common mangrove species, Avicennia marina, in NE Australia. Marine pollution bulletin, 56(9), 1668. https://doi.org/10.1016/j.marpolbul.2008.08.001

Duke, N.C., Bell, A. M., Pederson, D.K., Roelfsema, C. M., \& Nash, S. B. (2005). Herbicides implicated as the cause of severe mangrove dieback in the Mackay region, NE Australia: consequences for marine plant habitats of the GBR World Heritage Area. Marine Pollution Bulletin, 51(1-4), 308-324. https://doi.org/10.1016/j.marpolbul.2004.10.040

Edgar, L.A., \& Pickett-Heaps, J.D. (1984). Diatom locomotion. In Progress in phycological research, Vol.3 (Round, F. E. \& Chapman, G., editors), 47-88. Biopress, Bristol.

Esteves, S. M., Keck, F., Almeida, S. F., Figueira, E., Bouchez, A., \& Rimet, F. (2017). Can we predict diatoms herbicide sensitivities with phylogeny? Influence of intraspecific and interspecific variability. Ecotoxicology, 26(8), 1065-1077. https://doi.org/10.1007/s10646-017-1834-Z

Frankenbach, S., Schmidt, W., Frommlet, J.C., \& Serôdio, J. (2018). Photoinactivation, repair and the motility-physiology trade-off in microphytobenthos. Marine Ecology Progress Series, 601, 41-57. https://doi.org/10.3354/meps12670

Genty B, Briantais JM, Baker NR. 1989. The relationship between the quantum yield of photosynthetic electron transport and quenching of chlorophyll fluorescence. Biochimica et Biophysica Acta, 990: 87-92. https://doi.org/10.1016/S0304-4165(89)80016-9

Haynes, D., Ralph, P., Prange, J., \& Dennison, B. (2000). The impact of the herbicide diuron on photosynthesis in three species of tropical seagrass. Marine pollution bulletin, 41(7-12), 288-293.

43 https://doi.org/10.1016/S0025-326X(00)00127-2 
Hoagland, K.D., Rosowski, J.R., Gretz, M.R., \& Roemer, S.C. (1993). Diatom extracellular polymeric substances: function, fine structure, chemistry, and physiology. Journal of phycology, 29(5), 537-566. https://doi.org/10.1111/j.0022-3646.1993.00537.x

Holmes, G. (2014). Australia's pesticide environmental risk assessment failure: The case of diuron and sugarcane. Marine pollution bulletin, 88(1-2), 7-13. https://doi.org/10.1016/j.marpolbul.2014.08.007

Jones, R. (2005). The ecotoxicological effects of Photosystem II herbicides on corals. Marine Pollution Bulletin, 51(5-7), 495-506. https://doi.org/10.1016/j.marpolbul.2005.06.027

Jones, R. J., Muller, J., Haynes, D., \& Schreiber, U. (2003). Effects of herbicides diuron and atrazine on corals of the Great Barrier Reef, Australia. Marine Ecology Progress Series, 251, 153-167. http://doi.org/10.3354/meps251153

Juneau, P., Qiu, B., \& Deblois, C. P. (2007). Use of chlorophyll fluorescence as a tool for determination of herbicide toxic effect. Toxicological and Environ Chemistry, 89(4), 609-625. https://doi.org/10.1080/02772240701561569

Kelly, M.G., \& Whitton, B.A. (1995). The trophic diatom index: a new index for monitoring eutrophication in rivers. Journal of Applied Phycology, 7(4), 433-444. https://doi.org/10.1007/BF00003802

Kennedy, K., Schroeder, T., Shaw, M., Haynes, D., Lewis, S., Bentley, C., Paxman, C., Carter, S., Brando, V.E., Bartkow, M., Hearn, L. \& Mueller, J.F. (2012). Long term monitoring of photosystem II herbicides-Correlation with remotely sensed freshwater extent to monitor changes in the quality of water entering the Great Barrier Reef, Australia. Marine Pollution Bulletin, 65(4-9), 292-305. https://doi.org/10.1016/j.marpolbul.2011.10.029

Kumar, K. S., Choo, K.S., Yea, S.S., Seo, Y., \& Han, T. (2010). Effects of the phenylurea herbicide diuron on the physiology of Saccharina japonica Aresch. Toxicology and Environmental Health Sciences, 2(3), 188-199. http://doi.org/10.1007/BF03216505

Larras, F., Bouchez, A., Rimet, F. \& Montuelle, B. (2012) Using Bioassays and Species Sensitivity Distributions to Assess Herbicide Toxicity towards Benthic Diatoms. PLOS ONE 7(8): e44458. https://doi.org/10.1371/journal.pone.0044458

Lavaud, J., \& Goss, R. (2014). The peculiar features of non-photochemical fluorescence quenching in diatoms and brown algae. In Non-photochemical quenching and energy dissipation in plants, algae and cyanobacteria, Advances in Photosynthesis and Respiration 40. 421-443. Springer, Dordrecht. https://doi.org/10.1007/978-94-017-9032-1_20

Laviale, M., Barnett, A., Ezequiel, J., Lepetit, B., Frankenbach, S., Méléder, V., Serôdio, J., \& Lavaud, J. (2015). Response of intertidal benthic microalgal biofilms to a coupled light-temperature stress: evidence for latitudinal adaptation along the Atlantic coast of Southern Europe. Environmental microbiology, 17(10), 3662-3677. https://doi.org/10.1111/1462-2920.12728

Lewis, S. E., Schaffelke, B., Shaw, M., Bainbridge, Z. T., Rohde, K. W., Kennedy, K., Davis, A. M., Masters, B. L., Devlin, M. J., Mueller, J. F., \& Brodie, J. E. (2012). Assessing the additive risks of PSII herbicide exposure to the Great Barrier Reef. Marine Pollution Bulletin, 65(4-9), 280-291. https://doi.org/10.1016/j.marpolbul.2011.11.009

MacIntyre, H.L., Geider, R.J., \& Miller, D.C. (1996). Microphytobenthos: the ecological role of the "secret garden" of unvegetated, shallow-water marine habitats. I. Distribution, abundance and primary production. Estuaries, 19(2), 186-201. https://doi.org/10.2307/1352224

Magnusson, M., Heimann, K., \& Negri, A.P. (2008). Comparative effects of herbicides on photosynthesis and growth of tropical estuarine microalgae. Marine Pollution Bulletin, 56(9), 1545-1552. https://doi.org/10.1016/j.marpolbul.2008.05.023

Magnusson, M., Heimann, K., Quayle, P., \& Negri, A.P. (2010). Additive toxicity of herbicide mixtures and comparative sensitivity of tropical benthic microalgae. Marine Pollution Bulletin, 60(11), 1978-1987. https://doi.org/10.1016/i.marpolbul.2010.07.031

Magnusson, M., Heimann, K., Ridd, M., \& Negri, A.P. (2012). Chronic herbicide exposures affect the sensitivity and community structure of tropical benthic microalgae. Marine Pollution Bulletin, 65(4-9), 363-372. 
Maxwell, K , Johnson, G.N. (2000). Chlorophyll fluorescence--a practical guide. Journal of experimental botany, 51(345):659-668. https://doi.org/10.1016/S0304-4165(89)80016-9

Molino, P.J., \& Wetherbee, R. (2008). The biology of biofouling diatoms and their role in the development of microbial slimes. Biofouling, 24(5), 365-379. https://doi.org/10.1080/08927010802254583

Mukherjee, A., Rao, K.M., \& Ramesh, U.S. (2009). Predicted concentrations of biocides from antifouling paints in Visakhapatnam Harbour. Journal of environmental management, 90, S51-S59. https://doi.org/10.1016/j.jenvman.2008.07.018

Murchie, E.H., Lawson, T. (2013). Chlorophyll fluorescence analysis: a guide to good practice and understanding some new applications. Journal of Experimental Botony. 64:3893-3898. DOI: 10.1093/jxb/ert208

Negri, A.P., Flores, F., Mercurio, P., Mueller, J.F., \& Collier, C. J. (2015). Lethal and sub-lethal chronic effects of the herbicide diuron on seagrass. Aquatic Toxicology, 165, 73-83. https://doi.org/10.1016/j.aquatox.2015.05.007

Negri, A.P., Flores, F., Röthig, T., \& Uthicke, S. (2011). Herbicides increase the vulnerability of corals to rising sea surface temperature. Limnology and Oceanography, 56(2), 471-485. https://doi.org/10.4319/10.2011.56.2.0471

Negri, A., Vollhardt, C., Humphrey, C., Heyward, A., Jones, R., Eaglesham, G., \& Fabricius, K. (2005). Effects of the herbicide diuron on the early life history stages of coral. Marine Pollution Bulletin, 51(1-4), 370-383. https://doi.org/10.1016/j.marpolbul.2004.10.053

Nitschke, L., \& Schüssler, W. (1998). Surface water pollution by herbicides from effluents of waste water treatment plants. Chemosphere, 36(1), 35-41. https://doi.org/10.1016/S0045-6535(97)00286-5

OECD. (2002). Guideline for testing of chemicals. Proposal for updating guideline 201, freshwater alga and cyanobacteria, growth inhibition test., Organization for the Economic Cooperation and Development.

OECD. (2006). OECD Guideline 201. Guidelines for the testing of chemicals. Freshwater alga and cyanobacteria, growth inhibition test., Organization for the Economic Cooperation and Development.

https://doi.org/10.1787/9789264069923-en

Platt, T. G. C. L., Gallegos, C. L., \& Harrison, W. G. (1980). Photoinhibition of photosynthesis in natural assemblages of marine phytoplankton. Journal of Marine Research, 38(4), 687-701. https://images.peabody.yale.edu/publications/jmr/jmr38-04-06.pdf

Pniewski, F., \& Piasecka-Jędrzejak, I. (2020). Photoacclimation to constant and changing light conditions in a benthic diatom. Frontiers in Marine Science. https://doi.org/10.3389/fmars.2020.00381

Potapova, M., \& Charles, D.F. (2007). Diatom metrics for monitoring eutrophication in rivers of the United States. Ecological indicators, 7(1), 48-70. https://doi.org/10.1016/j.ecolind.2005.10.001

Serôdio, J., Coelho, H., Vieira, S., \& Cruz, S. (2006). Microphytobenthos vertical migratory photoresponse as characterised by light-response curves of surface biomass. Estuarine, Coastal and Shelf Science, 68(3-4), 547-556. https://doi.org/10.1016/j.ecss.2006.03.005

Shaw, M., Silburn, D.M., Thornton, C., Robinson, B., \& McClymont, D., (2011). Modelling pesticide runoff from paddocks in the Great Barrier Reef using HowLeaky. In MODSIM 2011 - 19th International Congress on Modelling and Simulation - Sustaining Our Future: Understanding and Living with Uncertainty. 2057-2063. https://www.mendeley.com/catalogue/44ec9b6d-cdfe-321e-86a1-320f5e314d7f/

Simões, M.D.S., Bracht, L., Parizotto, A.V., Comar, J.F., Peralta, R.M., \& Bracht, A. (2017). The metabolic effects of diuron in the rat liver. Environmental Toxicology and Pharmacology, 54, 53-61. https://doi.org/10.1016/j.etap.2017.06.024

Smith, R., Middlebrook, R., Turner, R., Huggins, R., Vardy, S., \& Warne, M. (2012). Large-scale pesticide monitoring across Great Barrier Reef catchments-paddock to reef integrated monitoring, modelling and reporting program. Marine pollution bulletin, 65(4-9), 117-127. https://doi.org/10.1016/j.marpolbul.2011.08.010 
Staats, N., Stal, L. J., de Winder, B., \& Mur, L. R. (2000). Oxygenic photosynthesis as driving process in exopolysaccharide production of benthic diatoms. Marine Ecology Progress Series, 193, 261-269. http://doi.org/10.3354/meps193261

Stachowski-Haberkorn, S., Jérôme M., Rouxel, J., Khelifi, C., Rincé, M., Burgeot, T. (2013). Multigenerational exposure of the microalga Tetraselmis suecica to diuron leads to spontaneous long-term strain adaptation, Aquatic Toxicology, 140-141, 380-388. https://doi.org/10.1016/j.aquatox.2013.06.016.

Stevenson, R.J., Pan, Y., \& Van Dam, H. (2010). Assessing environmental conditions in rivers and streams with diatoms. In The diatoms: applications for the environmental and earth sciences, 1(4),57-85. Cambridge University Press, Cambridge.

Stingaciu, L.R., O’Neill, H. M., Liberton, M., Pakrasi, H. B., \& Urban, V. S. (2019). Influence of chemically disrupted photosynthesis on cyanobacterial thylakoid dynamics in Synechocystis sp. PCC 6803. Scientific reports, 9(1), 1-9. https://doi.org/10.1038/s41598-019-42024-0

Tixier, C., Sancelme, M., Sancelme, M., Bonnemoy, F., Cuer, A., \& Veschambre, H. (2001). Degradation products of a phenylurea herbicide, diuron: synthesis, ecotoxicity, and biotransformation. Environmental Toxicology and Chemistry: An International Journal, 20(7), 1381-1389. https://doi.org/10.1002/etc.5620200701

US Government. 2005. Bureau of Land Management. Diuron Ecological Risk Assessment. Utah State University. Bureau of Land Management, United States, Reno, Nevada. pp 105.

Underwood, G.J.C. \& Kromkamp, J. (1999). Primary production by phytoplankton and microphytobenthos in estuaries. Advances in Ecological Research. 29, 93-153. http://doi.org/10.1016/S0065-2504(08)60192-0

USEPA. (1996). Ecological effects test guidelines OPPTS 850.5400. Algal toxicity, tiers I and II, United States Environmental Protection Agency.

Wood, R.J., Mitrovic, S.M., Lim, R.P., \& Kefford, B.J. (2016). How benthic diatoms within natural communities respond to eight common herbicides with different modes of action. Science of The Total Environment, 557-558, 636-643. https://doi.org/10.1016/j.scitotenv.2016.03.142.

Wong, A., de Vasconcelos Lanza, M.R., \& Sotomayor, M.D.P.T. (2013). Sensor for diuron quantitation based on the P450 biomimetic catalyst nickel (II) 1, 4, 8, 11, 15, 18, 22, 25-octabutoxy-29H, 31H-phthalocyanine. Journal of Electroanalytical Chemistry, 690, 83-88. https://doi.org/10.1016/j.jelechem.2012.11.007 